Myroslav Shkandrij. Avant-Garde Art in Ukraine, 19101930: Contested Memory. Boston: Academic Studies Press, 2019.

Reviewed by: Olena Martyniuk

Source: Kyiv-Mohyla Humanities Journal 7 (2020): 249-251

Published by: National University of Kyiv-Mohyla Academy

http://kmhj.ukma.edu.ua/ 


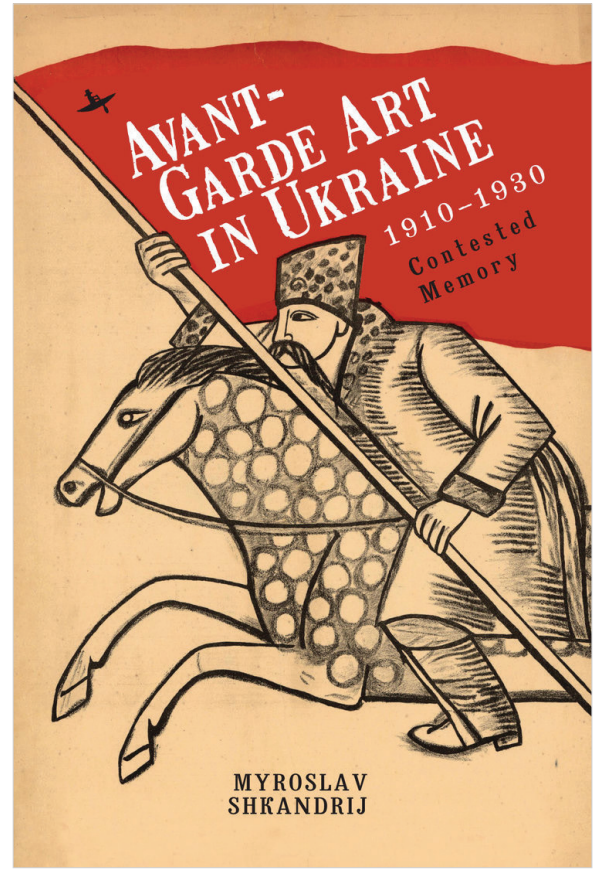

\title{
Myroslav Shkandrij
}

\author{
Avant-Garde Art in Ukraine, \\ 1910-1930: Contested Memory
}

\author{
Boston: Academic Studies Press, 2019. \\ $202 \mathrm{pp}$.
}

ISBN 978-1618119759

\section{Reviewed by Olena Martyniuk}

Myroslav Shkandrij's Avant-Garde Art in Ukraine, 1910-1930: Contested Memory is a timely and urgently needed publication, as it presents Ukraine as a versatile, multiethnic country capable of harboring and nourishing complex artistic and intellectual endeavors. The book should be praised as material testimony to the author's travails of many years in countering incredulity in the very category of the Ukrainian avant-garde and also in complicating this category, moving beyond nativist or ethnic approaches to the idea. This publication compiles many of Shkandrij's previously published and partially reworked materials from websites or strictly academic articles to book chapters, as it narrates the story of the "cultural ferment among artists from Ukraine" (p. xi). Through a versatile mosaic of painting, posters, sculpture, film, and literature, the author addresses previously overlooked specifics of the phenomenon that not only originate from Ukrainian territory, but are connected to it by their traits. While tackling the issue, Shkandrij shares a wealth of information based on archival research and his direct communication with some artists' families. The reader learns not only the biographies of the leading artists, but also essential historical context, including Ukrainization (as part of korenizatsiia policies) and a very useful periodization that encompasses the rise and fall of the avant-garde movement in Ukraine.

Like many authors working on understudied regions such as Ukraine, Shkandrij is compelled to combine field work with conceptualization, simultaneously filling gaps in factual knowledge and theoretic comprehension of the avant-garde in its Ukrainian dimension. Overtasked by the inherent complexity of his subject, the author muddles matters by attempting to weave some previously published materials together in one book, which suffers some inconsistencies and redundancies as a result. I refer to the excellent review by Oleh S. Ilnytzkyj, published on H-SHERA in March 2020, which 
names a few while giving an extensive outlook of the book's chapters. ${ }^{1}$ Additionally, in my opinion, the subject of the political involvement and ambitions of avant-garde artists disrupts the flow of the author's argument, as it is presented as inconsequential in some parts of the book and overarching in others.

The first chapter, "Forging the European Connection," presents the Ukrainian avant-garde as a movement prone to an organic worldview "rooted not in metaphysical or political abstraction, but in the observation of nature" (p. 21). Privileging the rural profusion of nature, harmony, and color to mechanical urban rhythms and the desire to reform the world, Ukrainian avant-gardists appear in Shkandrij's account to draw generously from peasant themes and folk topics. This argument is developed in the same chapter in small vignettes dedicated to the artists selected, wherein each artistic program is shown as a combination of modern European and Ukrainian rural influences. For Alexandra Exter it is her interest in primitivism and Parisian lessons of Cubism; for Alexander Archipenko it is ancient stone idols and the spirit of avant-garde Paris; for David Burliuk it is a merger of the Der Blaue Reiter expressionism and the Scythian art of the steppe; for Mykhailo Boichuk it is the Byzantine tradition reflected through the lens of the European avant-garde. The same line of argumentation unfolds in three of the five individual case studies in the third chapter: Burliuk, Kazimir Malevich, and Vadym Meller. In "David Burliuk and Steppe as Avant-Garde Identity," Shkandrij reverses the traditional order given for Burliuk's influences, bringing to center stage not Russian Futurism and its antagonism toward symbolism, but the steppe as a cosmos of barbarian vitality with Scythian ancient idols and the mystical Cossack Mamai representing the Ukrainian background as the "love of the prolific and irrepressible" (p. 94). In "Kazimir Malevich's Autobiography and Art," Shkandrij underscores the impact of his early years in Ukraine, peasant folk art colors and themes, in particular icons, a connection that resurfaces during his Suprematist period, actualized through his collaborations with Yevheniia Prybylska and Nataliia Davydova around 1915. The link resurfaces again towards the end of Malevich's career in his peasant cycles and work in the Kyiv Art Institute headed by Ivan Vrona. In "Vadym Meller and Sources of Inspiration in Theater Art," Shkandrij discusses the influence of the cottage crafts industry through Meller's second wife, Nina Henke, on Meller's dynamic compositions that, in turn, transformed dance and theater productions in Ukraine at the time.

However, the organic component as a strategic feature underlining the distinctiveness of the Ukrainian avant-garde recedes greatly in a second chapter, "Politics and Painting," as well as in the last two of the five case studies from the third, those dedicated to Ivan Kavaleridze and Dziga Vertov. Observation of nature gives way to the desire to transform and transcend it in Shkandrij's argument. He states in the beginning

1 Oleh S. Ilnytzkyj, Review of Avant-Garde Art in Ukraine, 1910-1930: Contested Memory by Myroslav Shkandrij, H-SHERA 3 (2O2O), accessed September 3, 202O, https://networks.hnet.org/node/166842/reviews/5984176/ilnytzkyj-shkandrij-avant-garde-art-ukraine-191o1930-contested. 
of the second chapter,, "Many avant-garde artists were both politically motivated and concerned with linking new ways of perceiving the world to the business of remaking it" (p. 25). This subchapter primarily concerns avant-garde Ukrainian literature and its entanglement with both national and Bolshevik projects of competing futures, the use of literature as overt and covert propaganda, and the fates of writers who, like Mykola Khvylovy, were trying to negotiate a modern Ukrainian identity and perished in the process. Followed by a discussion of Mykhailo Boichuk's school, its involvement with communist monumental propaganda, and its ultimate demise in the Stalinist purges, the two subchapters complete the martyrdom pantheon of the Ukrainian Executed Renaissance, although Shkandrij waits until later to introduce this term, in the chapter on Dziga Vertov (p. 152). The second chapter concludes by conflating the Ukrainian and Jewish avant-gardes which started as "allies in the struggle for civil rights and national emancipation" (p. 56), but parted ways after the end of korenizatsiia policies and the advent of Stalinism that started to take its toll on both. He addresses the founding and the activities of remarkably productive Kultur-Lige, which brought such luminaries as El Lissitzky and Marc Chagall into the orbit of the Kyiv avant-garde milieu.

Although Shkandrij is a leading literature scholar, the book offers a dense cultural portrait of the epoch, without concentrating on either visual artists or literary figures, but on the whole of multiethnic, cultural production in Ukraine during the avant-garde period. From an art historical perspective, however, the book would greatly benefit from more close and extended readings of artworks. For instance, I wish the author had elaborated more on his comparison of Vladimir Tatlin's monument to the Third International with the "splayed wooden strips used to make the bandura" (p. 22), or spent some time describing the concrete artworks of Maria Syniakova when comparing her usage of peasant imagery to Pablo Picasso's Les Demoiselles d'Avignon (1907) (pp. 34-35). Where Shkandrij's narration is very effective and convincing is in his previously unpublished chapter on Dziga Vertov. A thorough and engaging discussion of the first Ukrainian sound film Enthusiasm: Symphony of the Donbas (1931) and its embodiment of several avant-gardes (“Cultural Renaissance," proletarian, and Stalinist avant-gardes) crystalizes Shkandrij's argument.

Despite the interruptions in the flow of the argument about the Ukrainian avantgarde either observing nature or transforming the reality, Shkandrij's book is overall an important contribution to the field. It will undoubtedly prove an invaluable resource in teaching and as a further inspiration for inclusive studies on the regional modernisms flourishing in the Russian Empire and early Soviet Union, including Ukraine. 